\title{
"EFEKTIVITAS PENERAPAN METODE SOROGAN DENGAN KEMAMPUAN MEMBACA KITAB SAFINATUN NAJAH SANTRI PONDOK PESANTREN AL- INAAROH DESA MERTAPADA KULON KECAMATAN ASTANAJAPURA KABUPATEN CIREBON"
}

Oleh:

Shokhibul Fakhor, A. Syathori, Mahbub Nuryadien Pendidikan Agama Islam (PAI) FITK IAIN Syekh Nurjati Cirebon Email: Fakhors380@gmail.com, a.syatori@syekhnurjati.ac.id, mahbub.nuryadien.ac.id

\begin{abstract}
ABSTRAK
Penelitian ini memiliki latar belakang masalah yaitu masih terdapat beberapa santri putra yang mengikuti pembelajaran kitab Safinatun Najah dengan menggunakan metode sorogan namun masih belum lancar membaca kitab safinatun najah, ada juga yang sudah lancar membacanya namun masih kurang dalam memahami isi kitabnya. bacaan kitabnya sudah baik namun tidak mengetahui nahwu dan shorofnya. Padahal metode sorogan adalah metode yang efektif karena Ustadz/Kyai dapat langsung berhadapan langsung Head To Head langsung dengan murid atau santri Melalui sorogan, perkembangan intelektual santri dapat di ketahui oleh Asatidz secara utuh dan dapat memberikan bimbingan penuh kejiawaan sehingga dapat memberi tekanan pengajaran kepada santri tertentu atas dasar observasi langsung terhadap tingkat kemampuan dasar dan kapasitas para santri. Dengan metode sorogan, pembelajaran santri untuk membaca kitab lebih efektif. Penelitian ini bertujuan untuk mengetahui hubungan antara penerapan metode sorogan dengan kemampuan membaca kitab Safinatun Najah santri Pondok Pesantren Al- Inaaroh desa Mertapada Kulon kecamatan Astanajapura kabupaten Cirebon.
\end{abstract}

Metode yang digunakan dalam penelitian ini, yaitu kuantitatif, populasinya seluruh santri Pondok pesantren Al-Inaaroh dan sample yang peneliti ambil berjumlah 35 santri. Teknik pengumpulan datanya antara lain: angket, tes, observasi dan dokumentasi, sedangkan untuk teknik analisis data yaitu dengan

Jurnal Pendidikan Agama Islam

IAIN Syekh Nurjati Cirebon 
menggunakan rumus korelasi product moment. Berdasarkan hasil penelitian, jumlah skor rata-rata hasil angket tentang penerapan metode sorogan sebesar 3,24 dalam prosentase nilai sebesar $81,05 \%$ dan dapat dikategorikan baik sekali karena pada rentang nilai 75\%-100\%. Sedangkan kemampuan membaca kitab Safinatun Najah santri memiliki skor rata-rata hasil tes sebesar 80,37 dalam prosentase nilai sebesar 80,37\%, dan dapat dikategorikan cukup karena pada rentang nilai $71 \%$ $80 \%$. Dengan demikian dapat disimpulkan bahwa hubungan antara penerapan metode sorogan dengan kemampuan membaca kitab Safinatun Najah santri terdapat korelasi yang termasuk dalam kategori cukup tinggi $(0,54)$.

Kata kunci : Sorogan,Kemampuan Membaca, Safinatun Najah

\begin{abstract}
This study has a background problem that is there are still some male students who attended the study of Safinatun Najah using the sorogan method but still did not read the book Safinatun Najah smoothly, there were also those who had read it fluently but still lacked in understanding the contents of the book. the reading of the book was good but did not know the nahwu and the shorof. Even though the sorogan method is an effective method because Ustadz / Kyai can directly face Head To Head directly with students or santri Through sorogan, the intellectual development of the santri can be known by Asatidz in full and can provide full guidance for scholarship so as to put pressure on certain santri on the basis of direct observation of the level of basic abilities and capacities of the santri. With the sorogan method, the learning of santri to read books is more effective. This study aims to determine the relationship between the application of the sorogan method and the ability to read the Safinatun Najah santri book of AlInaaroh Islamic Boarding School in Mertapada Kulon village, Astanajapura subdistrict, Cirebon district.
\end{abstract}

The method used in this study, namely quantitative, the population of all santri Al-Inaaroh Islamic Boarding School and the samples that the researchers 
took were 35 students. Data collection techniques include: questionnaires, tests, observation and documentation, while for data analysis techniques that is by using the product moment correlation formula. Based on the results of the study, the average score of the questionnaire about the application of the sorogan method was 3.24 in the percentage value of $81.05 \%$ and could be categorized as excellent because of the value range of $75 \%-100 \%$. While the ability to read the book Safinatun Najah santri has an average score of 80.37 in the percentage value of $80.37 \%$, and can be categorized enough because in the range of values $71 \%-80 \%$. Thus it can be concluded that the relationship between the application of the sorogan method and the ability to read the Safinatun Najah santri book contained a correlation that was included in the fairly high category (0.54).

Keywords: Sorogan, Reading Ability, Safinatun Najah

\section{A. PENDAHULUAN}

Metode sorogan merupakan salah satu metode pembelajaran di pesantren tradisional, adapun istilah sororgan berasal dari kata sorog (jawa) yang berarti menyodorkan. Sebab setiap santri saling bergiliran menyodorkan kitab di hadapan kyai atau badal (pembantu kyai). ${ }^{1}$ Marwan menjelaskan, bahwa sistem sorogan sangat efektif di gunakan, karena dengan system ini seorang santri dapat menerima pelajaran dan pelimpahan nilai - nilai sebagai proses deliveri of culture di pesantren ${ }^{2}$. Pendapat demikian di dukung oleh Geertz dengan mengatakan bahwa metode sorogan memiliki ciri pemahaman yang sangat kuat pada pemahaman tekstual atau literal. Namun kerapkali tidak semua orang bisa menggunakan metode yang sama, karena setiap metode memiliki kelebihan dan kekuranga, seperti yang di ungkapkan Mujammil Qomar, bahwa penerapan metode sorogan menuntut kesabaran dan keuletan pengajar, dan juga santri yang di tuntut untk memiliki kedisiplinan yang tinggi, disamping itu penerapan metode

\footnotetext{
${ }^{1}$ Ridlwan Nasir, format pendidikan pesantren (pustaka pelajar:Yogyakarta, 2005)

${ }^{2}$ Marwan Saridjo, Sejarah Pondok Pesantren di Indonesia (Jakarta: Dharma Bhakti, 1982), 32.
} 
ini membutuhkan waktu yang lama yang berarti pemborosan, kurang efektif dan efisien. ${ }^{3}$ Salah satu pesantren yang menggunakan sistem sorogan dalam pengajaran kitab kuningnya dalam hal ini adalah kiab Safinatun Najah yaitu pondok pesantren Al- Inaaroh yang berada di desa mertapada kulon kecamatan astana japura kabupaten cirebon, yang di mana pesantren ini secara karakteristik termasuk kedalam pesantren salaf atau tradisional. Pondok Pesantren Al-Inaaroh adalah salah satu dari sekian banyak pondok pesantren yang berada di komplek besar pondok Buntet Pesantren, yang di dirikan oleh KH. Izuddin pada tahun 1984.

Kemampuan membaca kitab kuning santri di ukur dari mampu membaca kitab yang tidak memiliki tanda baca (harakat) atau lebih di kenal dengan istilah kitab gundul, karena dalam pemebelajaran kitab kuning erat Efektivitasnya dengan penguasan mufrodat (kata tunggal dalam bahasa arab), maka para santri di wajibkan belajar ilmu alat (sorof dan nahwu), oleh karena itu sangat terlihat jelas perbedaan hasil antara santri yang tidak menguasai ilmu alat dan yang menguasai ilmu alat dan begitu juga tingkat pemahaman santri dalam memahami suatu kitab kuning. Dalam proses pembelajaran kitab safinah di pondok pesantren Al- Inaaroh menggunakan metode sorogan yang dimana proses pembelajaran kitab Safinatun Najah berjalan dengan baik, santri di perintah membaca kitab Safinatun Najah satu persatu dengan memulai duduk secara berbaris kemudian satu persatu membaca bab atau bagian yang akan di bacanya, terlebih dahulu kyai atau ustadz dan memaknai, kemudian di ikuti santri setelah selesai membaca, santri yang duduk di belakangnya akan maju untuk membaca bagian yang akan di bacanya, demikian seterusnya pengajian di lakukan untuk kesempatan selanjutnya, santri akan menyodorkan bagian/bab berikutnya dan seterusnya, biasanya santri mengulang lagi apa yang dibaca di kamar dengan baik dan lancar. Akan tetapi

${ }^{3}$ Mujamil Qomar, Pesantren Dari Transformasi Metodologi Menuju Demokratisasi Institusi (Jakarta : Erlangga, 2002) 
kemampuan membaca santri Al- Inaaroh masih relatif rendah, maka muncul rumusan masalah, efektif tidakkah penerapan metode sorogan dengan kemampuan dalam membaca kitab safinatun najah santri Pondok Pesantren al-Inaroh Desa Mertapada Kulon Kecamatan Astanajapura Kabupaten Cirebon?

\section{B. LANDASAN TEORI}

Pembelajaran adalah upaya atau proses guru membelajarkan peserta didik secara aktif dan efektif untuk mencapai tujuan pembelajaran yang telah ditetapkan, yang dilakukan secara sengaja, terprogram, tersistem, terfasilitasi, terbimbing, terarah dan terorganisasi. ${ }^{4}$

Kitab Safinah memiliki nama lengkap "Safinatun Najah Fiima Yajibu `ala Abdi Ii Maulah" (perahu keselamatan di dalam mempelajari kewajiban seorang hamba kepada Tuhannya).

Kemampuan adalah kesanggupan untuk mengingat, artinya dengan adanya kemampuan untuk mengingat pada siswa berarti ada suatu indikasi bahwa siswa tersebut mampu untuk menyimpan dan menimbulkan kembali dari sesuatu yang diamatinya. ${ }^{5}$

Membaca merupakan suatu kegiatan atau proses kognitif yang berupaya untuk menemukan berbagai informasi yang terdapat dalam tulisan. Membaca memberikan banyak manfaat dan keuntungan dari segala aspek baik itu untuk masa kini maupun untuk masa yang akan datang. ${ }^{6}$

\section{METODOLOGI PENELITIAN}

1. Teknik Pengumpulan Data

a. Kuesioner/Angket

${ }^{4}$ Dirman dan Cicih Juarsih, Kegiatan Pembelajaran yang Mendidi (Jakarta: Rineka Cipta, 2014), 8.

${ }^{5}$ Abu Ahmadi, Psikologi Umum (Jakarta: Rineka Cipta, 1998), 70.

${ }^{6}$ Dalman, Keterampilan Membaca (Depok: PT Raja Grafindo Persada, 2014), 5.

Jurnal Pendidikan Agama Islam 
Kuesioner juga sering dikenal sebagai angket. Kuesioner suatu alat pengumpul informasi dengan cara menyampaikan sejumlah pertanyaan tertulis untuk menjawab secara tertulis pula oleh responden. Kuesioner seperti halnya interview, dimaksudkan untuk memperoleh informasi tentang diri responden atau informasi tentang orang lain. ${ }^{7}$

Angket ini digunakan untuk mengetahui efektivitas metode sorogan dan diisi oleh siswa dengan soal angket pernyataan 20 butir. Adapun penggunaan angket ini digunakan dengan menggunakan skala liket. Angket digunakan untuk memperoleh data tentang respon santri terhadap efektivitas metode sorogan.

b. Tes

Tes adalah suatu teknik atau cara yang digunakan dalam rangka melaksanakan kegiatan pengukuran, yang di dalamnya terdapat serangkaian pertanyaan atau latihan atau alat lain yang digunakan untuk mengukur keterampilan, pengetahuan, kecerdasan, kemampuan, atau bakat yang dimiliki oleh seseorang atau kelompok. ${ }^{8}$ Penilaian tes ini dapat diklasifikasikan menjadi tiga bagian, yaitu tes tertulis, tes perbuatan, dan tes lisan. Pada penelitian ini, peneliti menggunakan tes lisan untuk mengukur kemampuan membaca Kitab safinatun najah santri yang diperjelas dengan menggunakan rubrik penilaian.

c. Observasi

Observasi diartikan sebagai pengamatan dan pencatatan secara sistematik terhadap gejala yang tampak pada objek penelitian. ${ }^{9}$ Observasi merupakan kegiatan pengumpulan data dengan melakukan penelitian langsung terhadap kondisi lingkungan objek penelitian yang mendukung kegiatan penelitian, sehingga didapat gambaran secara jelas tentang

\footnotetext{
${ }^{7}$ Margono, Metodologi Penelitian Pendidikan (Jakarta: Rineka Cipta, 2010), 168.

${ }^{8}$ Ega Rima Wati, Kupas Tuntas Evaluasi Pembelajaran ( Jakarta: Kata Pena, 2016), 52.

${ }^{9}$ Margono, Metodologi Penelitian Pendidikan 158. 
kondisi objek penelitian tersebut. ${ }^{10}$ Teknik pengumpulan data bertujuan untuk memperoleh data dari kondisi Pondok PesantrenAl-Inaaroh.

d. Wawancara

Wawancara adalah suatu cara pengumpulan data yang digunakan untuk memperoleh informasi langsung dari sumbernya. Wawancara ini digunakan bila ingin mengetahui hal-hal dari responden secara lebih mendalam dan jumlah responden sedikit. Wawancara ini peneliti gunakan untuk mengetahui data-data secara mendalam terkait penerapan metode sorogandan kemampuan membaca Kitab safinatun najah santri putra pondok pesantrenAl-Inaaroh.

e. Dokumentasi

Untuk menghasilkan data penelitian yang mendalam maka perlu pengamatan yang mendalam pula serta menyeluruh. Observasi adalah pemusatan perhatian terhadap sebuah objek dengan menggunakan semua kemampuan panca indra (Jauhari, 2010: 30). ${ }^{11}$ Teknik ini dilakukan dengan cara pengambilan gambar dan dokumen-dokumen yang berhubungan dengan kegiatan pembelajaran kitab dan kemampuan membaca Kitab safinatun najah santri putra, serta profil pondok, struktur organisasi, jumlah santri, jumlah guru/ustadz dan sarana prasarana di Pondok Putra-Putri Al-Inaaroh.

2. Teknik Analisis Data

a. Analisis Deskriptif

Analisis deskriptif adalah suatu rumusan masalah yang berkenaan dengan pertanyaan terhadap keberadaan variabel mandiri, baik hanya

${ }^{10}$ Syofian Siregar, Statistik Parametrik untuk Penelitian Kuantitatif (Jakarta: Bumi Aksara, 2014), 34.

${ }^{11}$ Heri Jauhari, Panduan Penulisan Skripsi Teori dan Aplikasi (Bandung: CV Pustaka Setia, 2010), 30 . 
pada satu variabel atau lebih (variabel yang berdiri sendiri). ${ }^{12}$ Analisis data yang digunakan dalam penelitian ini ialah dilakukan dengan pendekatan perumusan kuantitatif dengan menggunakan skala prosentase. $^{13}$

b. Uji Korelasi

Korelasi yaitu suatu alat statistik, yang dapat digunakan untuk mencari hubungan antara dua variabel yang berbeda agar dapat menentukan tingkat hubungan antara variabel-variabel. ${ }^{14}$ Selanjutnya untuk memberikan interpretasi secara sederhana angka indeks korelasi " $r$ " product moment $\left(\mathrm{r}_{\mathrm{xy}}\right)$ diperlukan pedoman sebagai berikut: ${ }^{15}$

\section{PEMBAHASAN}

Pembelajaran adalah upaya atau proses guru membelajarkan peserta didik secara aktif dan efektif untuk mencapai tujuan pembelajaran yang telah ditetapkan, yang dilakukan secara sengaja, terprogram, tersistem, terfasilitasi, terbimbing, terarah dan terorganisasi. ${ }^{16}$ Pembelajaran dapatlah dikatakan juga sebagai kegiatan guru secara terprogram dalam desain instruksional untuk membuat peserta didik belajar secara aktif, yang menekankan pada penyediaan sumber belajar. ${ }^{17}$ Pembelajaran tidak hanya menuntut kecakapan kognitif (untuk hanya sekedar mengetahui saja) akan tetapi berlanjut kepada tahap afektif (pemahaman) yang kemudian berlanjut pada tahap psikomotorik (praktek). Hal ini dengan teori belajar yaitu bahwa belajar dianggap sebagai suatu sistem yang menyeluruh yang hendaknya memenuhi kriteria-kriteria kognitif, afektif dan

12 Sugiyono, Metode Penelitian Pendidikan Pendekatan Kuantitatif, Kualitatif dan $R \& D$ (Bandung: CV Alfabeta, 2016), 56.

${ }^{13}$ Anas Sudijono, Pengantar Evaluasi Pendidikan (Jakarta: PT Raja Grafindo Persada, 2012), 43.

${ }^{14}$ Syofian Siregar, Statistik Parametrik......... , 339.

${ }^{15}$ Syofian Siregar, Statistik Parametrik ............, 337.

${ }^{16}$ Dirman dan Cicih Juarsih, Kegiatan Pembelajaran yang Mendidik, .............., 8.

${ }^{17}$ Dimyati dan Mudjiono, Belajar dan Pembelajaran (Jakarta: Rineka Cipta, 2006), 297.

\section{Jurnal Pendidikan Agama Islam}

IAIN Syekh Nurjati Cirebon 
psikomotorik. $^{18}$ Proses pembelajaran yang membutuhkan pemahaman juga didukung oleh metode dalam pembelajaran tersebut. Untuk mendalami kitab-kitab klasik yang dajarkan di pondok pesantren menurut Nurcholish Majid biasanya dipergunakan system sorogan dan bandongan. Bandongan adalah pembelajaran yang inisiatifnya berasal dari Kiai sendiri baik dalam penentuan tempat, waktu maupun lebih-lebih lagi kitabnya. Sedangkan sorogan yaitu pembelajaran yang merupakan permintaan dari atau beberapa orang santri kepada kiainya untuk diajarkan kitab tertentu.

Pembelajaran sebagai suatu proses kegiatan, dari berbagai sumber secara umum dapat dikatakan terdiri atas tiga fase atau tahapan. Fase-fase/ tahapantahapan dalam proses pembelajaran yang dimaksud meliputi: tahap perencanaan, tahap pelaksanan, dan tahap evaluasi. Adapun dari ketiganya ini akan dibahas sebagaimana berikut:

1. Perencanaan

Urutan langkah mengajar ditentukan oleh banyak hal, antara lain:

a. Oleh tujuan pembelajaran yang hendak dicapai pada jam pelajaran itu. Jika tujuannya ketrampilan, maka urutan langkahnya ada; bila tujuan nya memehami konsep, maka urutannya akan berbeda, demikian seterusnya.

b. Oleh kemampuan guru, ada guru yang pandai berbicara; ia sebaiknya banyak menggunakan metode ceramah. Jika guru senang bernyanyi, ia dapat gunakan sebagai cara mengajar. Langkah-langkanya disesuaikan dengan tujuan pembelajaran.

c. Oleh keadaan alat-alat yang tersedia. Dalam proses pembelajaran seringkali digunakan alat-alat. Alat-alat itu menentukan langkah mengajar. Bila metode eksperimen yang digunakan maka alat-alat eksperimen harus tersedia. Bila tidak ada, maka metode itu diganti dengan metode yang lain.

${ }_{18}^{18}$ Popi Sopiatin dan Sohari S., Psikologi Islam dalam Perspektif Islam (Bogor: Penerbit Ghalia Indonesia, 2011), 31. 
d. Oleh jumlah murid. Bila muridnya banyak, katakanlah 100 orang dalam satu kelas, maka metode ceramah lebih baik daripada metode diskusi. ${ }^{19}$

2. Pelaksanaan Kegiatan

Kegiatan belajar mengajar adalah inti kegiatan dalam pendidikan. Segala sesuatu yang telah diprogramkan akan dilaksanakan dalam proses belajar mengajar. Dalam kegiatan belajar mengajar akan melibatkan semua komponen pembelajaran, kegiatan belajar akan menentukan sejauh mana tujuan yang telah ditetapkan dapat dicapai. ${ }^{20}$

Hakikat dari tahap pelaksanaan adalah kegiatan operasional pembelajaran itu sendiri. Dalam tahap ini, guru melakukan interaksi belajarmengajar melalui penerapan berbagai strategi metode dan tekhnik pembelajaran, pemanfaatan seperangkat media dan tentunya dengan tambahan pemahaman/ penguasaan teori pendidikan, prinsip mengajar, teori belajar dan yang lainnya yang relevan untuk proses pembelajaran. Dalam proses ini, ada beberapa aspek yang harus diperhatikan oleh seorang guru, diantaranya ialah: 1) aspek pendekatan dalam pembelajaran, 2) aspek Strategi, Metode dan Taktik

3. Evaluasi

Evaluasi adalah keseluruhan kegiatan pengukuran (pengumpulan data dan informasi), pengolahan, penafsiran dan pertimbangan untuk membuat keputusan tentang tingkat hasil belajar yang dicapai peserta didik setelah melakukan kegiatan belajar dalam upaya mencapai tujuan pembelajaran yang telah ditetapkan. Pada hakekatnya evaluasi merupakan suatu kegiatan untuk mengukur perubahan perilaku yang telah terjadi untuk dijadikan tolak ukur perencanaan dan pengembangan pembelajaran kedepannya. Seharusnya evaluasi tidak hanya dilakukan dengan mengadakan ulangan harian atau

\footnotetext{
${ }^{19}$ Ahmad Tafsir, Ilmu Pendidikan dalam Peerspektif Islam (Bandung: Rosdakarya, 2014), 132.

${ }^{20}$ Saeful Bahri Djamarah dan Aswan Zain, Strategi Belajar Mengajar (Jakarta: Rineka Cipta, 2014), 44.
} 
ulangan umum saja. Tetapi, hendaknya dilakukan tiap kali selesai proses pembelajaran dengan tujuan untuk mengetahui perubahan dan kemajuan peserta didik setiap kompetensi dasar dengan mencakup tiga aspek, yaitu aspek kognitif, afektif, psikomotorik. Moekijat mengemukakan teknik evaluasi belajar pengetahuan, keterampilan, dan sikap sebagai berikut:

a. Evaluasi belajar pengetahuan (kognitif), dapat dilakukan dengan ujian tulis, lisan, dan daftar isian pertanyaan.

b. Evaluasi belajar keterampilan (psikomotorik), dapat dilakukan dengan ujian praktek, analisis keterampilan dan analisis tugas serta evaluasi oleh peserta didik itu sendiri.

c. Evaluasi belajar sikap (afektif), dapat dilakukan dengan daftar sikap isian dari diri sendiri, daftar isian sikap yang disesuaikan dengan tujuan program. $^{21}$

Kitab kuning sebagai salah satu unsur mutlak dari proses belajar mengajar di pesantren sangat penting sangat penting dalam membentuk kecerdasan intelektual dan moralitas kesalehan (kualitas keberagamaan) pada diri santri. Dalam catatan Nurcholish Madjid, setidaknya kitab-kitab klasik ini mencakup cabang ilmu-ilmu fiqih, tauhid, tasawuf dan nahwu-sharaf. Atau dapat juga dikatakan konsentrasi keilmuan yang berkembang di pesantren pada umumnya mencakup tidak kurang dari 12 macam disiplin keilmuan; nahwu, sharaf, balaghah, tauhid, fiqih, ushul fiqih, qawaid fiqhiyah, tafsir, hadits, muthalah alhadits, tasawuf dan mantiq. Gambaran yang mendetail tentang rincian kitab-kitab klasik yang dipelajari di pesantren mengindikasikan kekayaan hasanah keilmuan pada lembaga pendidikan itu, sehingga dipesantren ada nuansa kultural, akhlak, ilmu, karomah, integritas keimanan, kefaqihan dan sebagainya. ${ }^{22}$.Kitab Safinatun Najah berisi tentang dasar-dasar ilmu fiqih seperti bab dasar-dasar syari'at, kemudian bab bersuci, bab shalat, bab zakat dan bab puasa, kitab ini di susun oleh

${ }^{21}$ Oemar Hamalik, Proses Belajar Mengajar (Jakarta: Bumi Aksara, 2004), 159.

${ }^{22}$ Yasmadi, Modernisasi Pesantren (Ciputat: Quantum Teaching, 2005), 68-70. 
Syekh Salim bin Sumair Al- Hadhrami. Tujuan utama di susunnya kitab ini adalah agar masyarakat dapat bersuci dan beribadah dengan baik dan benar menurut fiqih. Kitab ini banyak diajarkan dihampir tiap-tiap madrasah dan pondok pesantren di seluruh Indonesia.

Hasil angket dicari seberapa besar presentase penerapan metode sorogan (Variabel X), dengan menggunakan langkah-langkah sebagi berikut:

$$
\begin{aligned}
& \text { Menentukan rata-rata }: \frac{\sum \mathrm{X}}{\text { total item }} \\
& =\frac{64,84}{20}=3,242 \\
& \text { Menentukan kategori }: \frac{\mathrm{X}}{\text { skor maks }} \times 100 \% \\
& =\frac{3,242}{4} \times 100 \% \\
& =81,05 \%
\end{aligned}
$$

Berdasarkan perhitungan di atas, maka diperoleh rata-rata penerapan metode sorogan sebesar 3,242 dengan presentase sebesar 81,05\%. Dengan demikian dapat disimpulkan bahwa penerapan metode sorogansantri putra pondok pesantren Al-Inaaroh Desa Mertapada Kulon Kecamatan Astanajapura Kabupaten Cirebon dikategorikan baik sekali karena pada rentang nilai $75 \%-100 \%$.

Kemampuan adalah kesanggupan untuk mengingat, artinya dengan adanya kemampuan untuk mengingat pada siswa berarti ada suatu indikasi bahwa siswa tersebut mampu untuk menyimpan dan menimbulkan kembali dari sesuatu yang

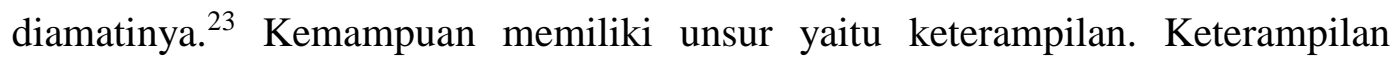
merupakan salah satu unsur kemampuan yang dapat dipelajari pada unsur penerapannya. Suatu keterampilan merupakan keahlian yang bermanfaat untuk jangka panjang. ${ }^{24}$ Sedangkan membaca merupakan suatu kegiatan atau proses kognitif yang berupaya untuk menemukan berbagai informasi yang terdapat dalam tulisan. ${ }^{25}$ Membaca memberikan banyak manfaat dan keuntungan dari

${ }^{23}$ Abu Ahmadi, Psikologi Umum (Jakarta: Rineka Cipta, 1998), 70.

${ }^{24}$ Muhammad Nurdin, Kiat Menjadi Guru Profesional (Jogjakarta: Prismasophie, 2004),144.

${ }^{25}$ Dalman, Keterampilan Membaca, 5 . 
segala aspek baik itu untuk masa kini maupun untuk masa yang akan datang. Selain itu, membaca juga akan membuat tata bahasa dan tutur kata seseorang menjadi lebih baik, sehingga akan terhindar dari kesalahan-kesalahan. Terlebih lagi membaca kitab Safinatun Najah yang mempelajari cara bersuci dan beribadah dengan baik.

Kitab Safinah memiliki nama lengkap "Safinatun Najah Fiima Yajibu `ala Abdi Ii Maulah" (perahu keselamatan di dalam mempelajari kewajiban seorang hamba kepada Tuhannya). Kitab ini walaupun kecil bentuknya akan tetapi sangatlah besar manfaatnya. Di setiap kampung, kota dan negara hampir semua orang mempelajari dan bahkan menghafalkannya, baik secara individu maupun kolektif, karena baik para santri maupun para ulama sangatlah gemar mempelajarinya dengan teliti dan seksama. Hal ini terjadi karena beberapa faktor, di antaranya: ${ }^{26}$

1) Kitab ini mencakup pokok-pokok agama secara terpadu, lengkap dan utuh, dimulai dengan bab dasar-dasar syari'at, kemudian bab bersuci, bab shalat, bab zakat dan bab puasa.

2) Kitab ini disajikan dengan bahasa yang mudah, susunan yang ringan dan redaksi yang gampang untuk dipahami serta dihafal. Seseorang yang serius dan memiliki kemauan tinggi akan mampu menghafalkan seluruh isinya hanya dalam masa dua atau tiga bulan atau mungkin lebih cepat.

3) Kitab ini ditulis oleh seorang ulama yang terkemuka dalam berbagai bidang ilmu keagamaan, terutama fiqh dan tasawwuf. Yang sangat menarik, orang lebih mengenal nama kitabnya dari pada nama penulisnya. Hal yang demikian itu mungkin saja berkat keikhlasan dan ketulusan penulis.

4) Kitab ini menjadi acuan para ulama dalam memberikan pengetahuan dasar agama bagi para pemula.

${ }^{26}$ Zamakhsyari Dhafir, tradisipesantren study tentang pandangan hidup kyai, (Jakarta: Lp3es, 1983) 
5) Kitab ini membicarakan hal-hal yang selalu menjadi kebutuhan seorang muslim dalam kehidupan sehari-hari, sehingga semua orang merasa perlu untuk mempelajarinya

Tes kemampuan membaca kitab Safinatun Najah dengan menggunakan tes lisan. Adapun hasil tes lisan santri putra pondok pesantren Al-Inaaroh Desa Mertapada Kulon Kecamatan Astanajapura Kabupaten Cirebon, yaitu:

Hasil tes dicari seberapa besar presentase kemampuan membaca kitab Safinatun Najah (Variabel Y), dengan menggunakan langkah-langkah sebagai berikut:

1. Menentukan Rata-rata : $\frac{\sum X}{\text { Total Item }}=\frac{2974}{37}=80,37$

2. Menentukan Kategori : $\frac{\bar{X}}{\text { Skor Maks }} \times 100 \%=\frac{80,37}{100} \times 100 \%=80,37 \%$

Berdasarkan rekapitulasi rata-rata hasil tes variabel Y mengenai tingkat kemampuan membaca Kitab safinatun najah, maka dapat diambil kesimpulan bahwa tingkat kemampuan membaca kitab Safinatun Najah santri putra Pondok Pesantren Al-Inaaroh Desa Mertapada Kulon Kecamatan Astanajapura Kabupaten Cirebon termasuk dalam kategori cukup, dengan nilai 80,37\% karena berada pada interval $71 \%-80 \%$.

Teknik analisis data yang digunakan dalam penelitian ini adalah analisis deskriptif dan uji korelasi untuk menghitung hubungan antara variabel $\mathrm{x}$ dan $\mathrm{y}$ dengan menggunakan rumus korelasi product moment. Kesimpulan dari penelitian ini adalah : 1) Penerapan metode sorogandi Pondok PesantrenAlInaaroh, Desa Mertapada Kulon, Kec. Astanajapura, Kab. Cirebon dikategorikan baik sekali dengan presentase sebesar $81,05 \%$. 2) Kemampuan membaca Kitab Safinatun Najah santri putra di Pondok Pesantren Al-Inaaroh, Desa Mertapada Kulon, Kec. Astanajapura, Kab. Cirebon dikategorikan cukup dengan presentase sebesar 80,37\%. 3) Terdapat hubungan yang signifikan antara Penerapan metode sorogan dengan Kemampuan membaca kitab Safinatun Najah santri. 


\section{E. KESIMPULAN}

Berdasarkan hasil penelitian tentang efektivitas penerapan metode sorogan dengan kemampuan membaca kitab Safinatun Najah santri di Pondok Pesantren Al-Inaaroh, Desa Mertapada Kulon, Kec. Astanajapura, Kab. Cirebon yang telah dilakukan dapat disimpulkan ke dalam tiga poin yakni:

1. Penerapan metode sorogan di Pondok Pesantren Al-Inaaroh, Desa Mertapada Kulon, Kec. Astanajapura, Kab. Cirebon berdasarkan perhitungan angket yaitu dengan hasil rata-rata sebesar 3,24 dengan presentase sebesar $81,05 \%$, dengan demikian dapat dikategorikan baik sekali karena pada rentang nilai $75 \%-100 \%$.

2. Kemampuan membaca kitab safinatun najah santri putra di Pondok Pesantren Al-Inaaroh, Desa Mertapada Kulon, Kec. Astanajapura, Kab. Cirebon berdasarkan perhitungan tes yaitu dengan hasil rata-rata sebesar 80,73 dengan presentase sebesar 80,37\%, dengan demikian dapat dikategorikan cukup karena pada rentang nilai $71 \%-80 \%$.

3. Efektivitas penerapan metode sorogan dengan kemampuan membaca kiatab safinatun najah santri di Pondok Pesantren Al-Inaaroh, Desa Mertapada Kulon, Kec. Astanajapura, Kab. Cirebon memiliki tingkat korelasi cukup. Hal ini dapat dibuktikan dari perhitungan koefisien korelasi dengan nilai 0,546 yang berada pada interval 0,40 - 0,599. Pengaruh penerapan metode sorogan terhadap kemampuan membaca kitab safinatun najah santri sebesar 29,81\% sedangkan sisanya sebesar 70,19\% dipengaruhi oleh faktor lain yang tidak peneliti teliti dan dapat mempengaruhi kemampuan santri dalam membaca kitab safinatun najah, seperti faktor lingkungan, bimbingan dari pengurus, wibawa sang guru, dan lain-lain. Dalam penelitian ini degrees of freedom nya adalah $\mathrm{df}=37$ $2=35$, pada tabel nilai-nilai " $r$ " product moment dapat diketahui pada taraf signifikansi $5 \%$ harga " $r$ " adalah 0,334 . Sedangkan perolehan $\mathrm{r}_{\text {hitung }} 0,546$ 
lebih besar dari $r_{\text {tabel }}$ baik pada taraf signifikansi $5 \%(0,546>0,334)$. Maka jika $r_{\text {hitung }}>r_{\text {tabel }} \mathrm{Ha}$ diterima dan Ho ditolak. Artinya terdapat korelasi positif antara penerapan metode sorogan dengan kemampuan membaca kitab safinatun najah santri putra pondok pesantren Al-Inaaroh Desa Mertapada Kulon Kecamatan Astanajapura Kabupaten Cirebon. Efektivitas antara variabel $\mathrm{x}$ dan variabel y signifikan secara statistik, artinya semakin baik penerapan metode sorogan berhubungan dengan tingginya kemampuan membaca kitab safinatun najah santri. Demikian pula sebaliknya jika penerapan metode sorogan yang buruk akan mempengaruhi rendahnya kemampuan membaca kitab safinatun najah santri.

\section{DAFTAR PUSTAKA}

Ahmadi, Abu. 1998. Psikologi Umum. Jakarta: Rineka Cipta.

Azra, Azyumardi. 2012. Pendidikan Islam: Tradisi dan Modernisasi di Tengah

Tantangan Milenium III. Jakarta: Kencana Predana Media Group.

Dalman, 2014. Keterampilan Membaca, Depok: PT Raja Grafindo Persada.

Dhafir, Zamakhsyari, 1983. TradisiPesantren Study tentang Pandangan Hidup Kyai, LP3ES, Jakarta.

Dimyati dan Mudjiono. 2006. Belajar dan Pembelajaran. Jakarta: Rineka Cipta.

Dirman dan Cicih Juarsih. 2014. Kegiatan Pembelajaran yang Mendidik. Jakarta: Rineka Cipta.

Hamalik, Oemar. 2004. Proses Belajar Mengajar, Jakarta: Bumi Aksara.

Jauhari. Heri. 2010. Panduan Penulisan Skripsi Teori dan Aplikasi. Bandung: CV Pustaka Setia.

Margono, 2010. Metodologi Penelitian Pendidikan. Jakarta: Rineka Cipta.

Nasir, ridlwan, 2005. format pendidikan pesantren, pustaka pelajar: Yogyakarta.

Nurdin, Muhammad, 2004. Kiat Menjadi Guru Profesional. Jogjakarta: Prismasophie. 
Qomar, Mujamil, 2002. Pesantren Dari Transformasi Metodologi Menuju Demokratisasi Institusi. Jakarta: Erlangga.

Said, Nur \& M. Izzul Mutho, 2016. Santri Membaca Zaman. Kudus: Santri Menara Pustaka.

Saridjo, Marwan, 1982. Sejarah Pondok Pesantren di Indonesia. Jakarta: Dharma Bhakti

Siregar, Syofian. 2014. Statistik Parametrik untuk Penelitian Kuantitatif. Jakarta: Bumi Aksara.

Sopiatin, Popi dan Sohari S. 2011. Psikologi Islam dalam Perspektif Islam. Bogor: Penerbit Ghalia Indonesia.

Sudijono, Anas, 2012. Pengantar Evaluasi Pendidikan. Jakarta: PT Raja Grafindo Persada.

Sugiyono, 2016. Metode Penelitian Pendidikan Pendekatan Kuantitatif, Kualitatif dan $R \& D$. Bandung: CV Alfabeta.

Tafsir, Ahmad, 2014. Ilmu Pendidikan dalam Peerspektif Islam. Bandung: Rosdakarya.

Wati, Ega Rima, 2016. Kupas Tuntas Evaluasi Pembelajaran. Kata Pena. 